\title{
A Gender Analysis of The Ngudi Rejeki Women Farmer Group Empowerment Program in Trirenggo Village, Bantul Regency to Support Local Product Development
}

\author{
Wiji Tuhu Utami \\ Agricultural Communication and \\ Extension \\ Sebelas Maret University \\ Surakarta, Indonesia \\ wijituhu@gmail.com
}

\author{
Retno Setyowati \\ Agricultural Communication and \\ Extension \\ Sebelas Maret University \\ Surakarta, Indonesia \\ rretnoo@yahoo.com
}

\author{
Sugihardjo \\ Agricultural Communication and \\ Extension \\ Sebelas Maret University \\ Surakarta, Indonesia \\ giek_bb@yahoo.com
}

\begin{abstract}
Ngudi Rejeki Women Farmer Group is a group that aims to make its members earn income with its famous product, namely processed products made from moringa leaves. Ngudi Rejeki Women Farmer Group has the right and the obligation to be involved in every village development process. Every empowerment program has advantages and disadvantages. The research aimed to analyze the empowerment program organized by Trirenggo Village for Ngudi Rejeki Women Farmer Group. The method used in this research was descriptive qualitative; meanwhile, the program evaluation used the Moser gender analysis technique. The results showed that not all Ngudi Rejeki Women Farmer Group members make processed products made from moringa leaves, and there were still problems in the empowerment program. The activities of Ngudi Rejeki Women Farmer Group have accommodated reproductive, productive, and social roles. There were practical and strategic gender needs that had not been met. Policy programs that can be implemented include: fostering group organizing, cultivating moringa plants in the village environment, developing capacity and product marketing networks, and developing variants of processed products made from moringa leaves.
\end{abstract}

Keywords-gender analysis, Moser, women empowerment

\section{INTRODUCTION}

The village is defined as a legal community unit that has territorial boundaries that are authorized to regulate and administer government affairs and the interests of the local community, based on community initiatives, rights of origin, and/or traditional rights that are recognized and respected in the government system of the Unitary State Republic of Indonesia [1]. Each village has its government tasked with carrying out government affairs and community interests through development programs. Village development is an effort to improve the life quality and life for the maximum welfare of the Village community. Village development is part of national development, so village development refers to the national development plan [2].

Village development is reflected in the existence of a development plan every year. Each year, the development program is compiled in the Village Development Work Plan, which elaborates the fiveyear development plan in the Village Medium-Term Development Plan. Management of village development optimally requires integrated development in the form of a Village Government Work Plan to achieve certainty in the achievement of development goals as formulated in the vision and mission of the Village Development Plan. It is essential in the government administration and development framework [3]. Women have the same role as men in development, both as subjects and objects of development. The agricultural sector still contributes quite a lot of farmer jobs in rural areas, in which women farmers play some crucial roles in every farming process.

Trirenggo Village is one of the villages near Bantul Regency center, which is surrounded by agricultural land. Farmers in Trirenggo Village gather in a farmer group forum shaded by a Combined Farmer Group (Gapoktan). There are 16 farmer groups and a Women Farmer Group. The focus of farming carried out by each farmer group, and the Women Farmer Group is different. Farmer groups focus on land agriculture, while Women Farmer Group focuses on manufacturing processed products. Even though they both work in the agricultural sphere and are 
covered by the Combined Farmer Group, farmer groups and Women Farmer Group have different needs to develop existing potentials to improve family welfare. Fulfilling these needs can be pursued through farmer empowerment programs organized by the village government based on community aspirations. The success of the village government in carrying out the village development program cannot be separated from the participation of the community in the implementation of existing development [4].

Villages are at the forefront of development movement efforts originating from community initiatives to achieve prosperity while being fair and sustainable [5]. Ngudi Rejeki Women Farmer Group is an association of women farmers whose main activity is processing well-known agricultural products, namely processed products made from moringa leaves, and helping in promoting the village repute. The village government provides support for organizational and member development through empowerment programs. Every empowerment program has advantages and disadvantages. Therefore, it was necessary to carry out a gender analysis to determine the level of program policy and measure the program's success rate so that a program will be right on target. The results of this analysis were useful for reformulating the program according to the problems and needs of the Ngudi Rejeki Women Farmer Group.

\section{RESEARCH METHODOLOGY}

The method used in this research was descriptive qualitative. The research process was conducted in Trirenggo Village, Bantul, which had a group of women farmers focusing on making processed products. The determination of informants was carried out by purposive sampling involving the village government, Ngudi Rejeki Women Farmer Group members, and field agricultural extension agents. The types of data used were primary and secondary data in both qualitative and quantitative forms. The data were collected using participatory observation techniques, in-depth interviews, and documentation, then analyzed using the Interactive Analytical Model by Miles and Huberman and Moser Gender Analysis Framework. The data validity used source triangulation and technique triangulation methods.

\section{RESULTS AND DISCUSSION}

\section{A. Ngudi Rejeki Women Farmer Group Processed Production}

Ngudi Rejeki Women Farmer Group is one of the women's association organizations at the village level whose main activity is the manufacture of processed food to get additional income for the family. Ngudi Rejeki Women Farmer Group is famous for its processed products made from moringa. The basic ingredients of this processed product come from the moringa plant grown in the house's yard. The production process is carried out individually in each member's house. This processed product has become a group entity that promotes the reputation of the village. Percentage of business form members of Ngudi Rejeki Women Farmer Group:

TABLE I. BUSINESS FORMS OF NGUDI REJEKI WOMEN FARMER GROUP MEMBERS

\begin{tabular}{|l|c|}
\hline \multicolumn{1}{|c|}{ Business Forms } & Percentage \\
\hline Producers made from Moringa leaves & $43.75 \%$ \\
\hline $\begin{array}{l}\text { Producers made from Moringa leaves and other } \\
\text { basic ingredients }\end{array}$ & $37.5 \%$ \\
\hline Producers made from other than Moringa leaves & $56.25 \%$ \\
\hline Members with more than one job & $25 \%$ \\
\hline Members of non-processed food producers & $37.5 \%$ \\
\hline
\end{tabular}

Only about $18.75 \%$ of the members are actively producing processed products made from moringa leaves. This is motivated by:

- Already having other processed products or other jobs that generate a more stable income than moringa leaf products made. These other processed products have a more accessible production process than the production processes of moringa leaf products.

- Carrying out caring activities such as caring for children who still need guidance because their spouse is working, caring for grandchildren who are being entrusted by their working children, or caring for other family members who need assistance.

- Feeling that market opportunities for moringa leaf processed products are challenging because not many people know the benefits of moringa leaves. There is also a lack of salvation for particular moringa leaf processed products in some events where the Women Farmer Group usually participates. Besides, people who want to process can pick and process the moringa leaf by themselves because there are many moringa trees around their village.

- Lacking adaptability to online-based marketing due to a lack of ability to use this media; thus, only a few members participate in marketing products online.

- Lacking encouragement or bravery from themselves to further develop their potential due to inadequate facilities and infrastructure. Besides that, some members are satisfied with the products' results or are still waiting for help from other parties to develop their business.

\section{B. Ngudi Rejeki Women Farmer Group Empowerment \\ Program}

The village government has a significant share in supporting Ngudi Rejeki Women Farmer Group, which is implemented through an empowerment program. The empowerment program that was held 
resulted from the formulation of the village development planning forum that the Ngudi Rejeki Women Farmer Group also attended. The empowerment program for Ngudi Rejeki Women Farmer Group in 2019 included: (1) assistance for drying moringa leaves so that the moringa leaves were not exposed to direct sunlight; (2) meeting budget for three meetings worth 8,000 rupiahs for each person by attaching attendance lists, meeting minutes, and receipts for consumption expenditures; (3) training for the manufacture of processed meat products which was a continuous program from the province with preparation and presenters were submitted to extension workers and members who had received training from the province. Based on the three programs, the programs related to the development of moringa leaf products were the assistance program for drying moringa leaves and budget meetings. There was a problem with the program for helping the moringa leaf drying tool, in which the tool was still used individually because not all members needed it. On the other hand, some members had not developed due to limited capital to buy equipment. Problems in the training program for the manufacture of processed meat-based products, namely the fully submitted preparation to Ngudi Rejeki Women Farmer Group and constrained by the lack of costs to buy training support tools that resulted in having to find other sources of funds. It resulted in the lack of application of training results.

\section{Moser Gender Analysis Framework}

The gender analysis technique used in this research was the Moser gender analysis framework. The Moser analysis technique is an analytical technique that helps planners or researchers assess, evaluate, and formulate proposals at the policy level of more gender-sensitive programs and projects [6]. The core of the Moser gender analysis framework includes three concepts, namely three roles of women, practical and strategic gender needs, and the category of the Women and Development (WAD) or Gender in Development (GID) policy approach (policy matrix) [7]. The gender analysis in this research was used to reformulate the empowerment program for Ngudi Rejeki Women Farmer Group to develop processed products made from moringa leaves.

The profile component identified three roles that women farmers played in the aspects of local products and representation in forums that supported the empowerment of women farmers and empowerment programs organized by the village government in 2019. Reproductive and productive roles were interrelated with one another. The programs or activities carried out in a productive role could be done for a reproductive role. The difference was that the women farmers did not get wages on the reproductive role, but they got wages on the productive role, especially from the production of processed food that had been traded. The social role of the community was a community activity that was followed and a program that supported the role. Table II. was a profile of Ngudi Rejeki Women Farmer Group activities:

TABLE II. ProfiLe OF EMPOWERMENT Program Activities

\begin{tabular}{|c|c|c|c|}
\hline \multirow{2}{*}{ Activities } & \multicolumn{3}{|c|}{ Role } \\
\hline & Reproductive & Productive & Social \\
\hline $\begin{array}{l}\text { 1. General } \\
\text { a. Cultivating the } \\
\text { Moringa plant } \\
\text { b. Processed } \\
\text { production made } \\
\text { from Moringa leaves } \\
\text { c. Internal } \\
\text { Organization } \\
\text { (Women Farmer } \\
\text { Group) } \\
\text { d. Collective } \\
\text { Organization } \\
\text { (Gapoktan) } \\
\text { e. Village meetings } \\
\end{array}$ & $\checkmark$ & $\checkmark$ & $\begin{array}{l}\checkmark \\
\checkmark\end{array}$ \\
\hline $\begin{array}{l}\text { 2. Empowerment } \\
\text { Program } \\
\text { a. Assistance Drying } \\
\text { tools for drying } \\
\text { moringa leaves } \\
\text { b. Training for the } \\
\text { manufacture of } \\
\text { processed meat } \\
\text { products } \\
\text { c. Group meeting } \\
\text { budget } \\
\end{array}$ & $\checkmark$ & $\checkmark$ & $\checkmark$ \\
\hline
\end{tabular}

Based on table 2, the cultivation of moringa plants and the production of processed moringa leaves have two purposes, namely to be used for reproductive roles such as cooking food for family members and trading the Moringa leaves, and other products processed to support a productive role. The social role of the community is carried out through participation in Women Farmer Group organizations, Gapoktan, and forums at the village level to realize the empowerment of Ngudi Rejeki Women Farmer Group members. The assistance provided for drying moringa leaves and the application of training results in making processed food from meat also supports the implementation of the reproductive role, namely cooking and supporting the production process in the productive role of moringa leaf processing, training in making processed meat-based products which have the opportunity to open new businesses to earn income. The funding assistance program for group meetings is classified as a social community role because group meetings are one of the activities in the social community, these activities are useful for reducing the burden on group costs in activities that are routinely carried out every month.

The fundamental point of the Moser concept is the need to pay attention to gender-specific needs including practical needs and strategic needs. Practical needs are short-term, lighten women's workloads, and are easier to meet. Strategic needs are more long-term, refer to women's ideal roles, change gender relations, and require specific strategies in the fulfillment 
process [6]. The following are the results of the identification of practical and strategic gender needs:

TABLE III. IDENTIFICATION OF GENDER NEEDS OF NGUDI REJEKI WOMEN FARMER GROUP

\begin{tabular}{|c|c|c|}
\hline \multirow{2}{*}{ Type of Intervention } & \multicolumn{2}{|c|}{ Gender Needs } \\
\hline & Practical & Strategic \\
\hline $\begin{array}{l}\text { a. Welfare } \\
\text { 1) The assistance of moringa leaves } \\
\text { drying tools }\end{array}$ & $\begin{array}{l}\text { a) Use of moringa leaves drying tools for } \\
\text { family } \\
\text { consumption needs }\end{array}$ & - \\
\hline $\begin{array}{l}\text { b. Equality } \\
\text { 1)Representation in Village } \\
\text { deliberation forums } \\
\text { 2)Representation in Gapoktan } \\
\text { 3)The budget stimulus for group } \\
\text { meetings }\end{array}$ & $\begin{array}{l}\text { a) Participate in Village deliberation forums } \\
\text { a) Joined in Gapoktan organizations } \\
\text { a) Reduced expenditure for Group }\end{array}$ & $\begin{array}{l}\text { a) Handling of problems by the village } \\
\text { government } \\
\text { a) Active participation in Gapoktan } \\
\text { a) Ongoing group meetings }\end{array}$ \\
\hline $\begin{array}{l}\text { 2)The assistance of moringa leaves } \\
\text { drying tools } \\
\text { 3)Processed production made from } \\
\text { moringa leaves }\end{array}$ & $\begin{array}{l}\text { a) Moringa plant maintenance } \\
\text { b) Use of moringa leaves for household } \\
\text { consumption } \\
\text { a) Use of moringa leaves drying tools for } \\
\text { production } \\
\text { a) Get money from the sale of processed } \\
\text { products }\end{array}$ & $\begin{array}{l}\text { a) Conservation of moringa plants } \\
\text { b) The sale of moringa leaves } \\
\text { - } \\
\text { a) The ability to use a promotional } \\
\text { strategy }\end{array}$ \\
\hline $\begin{array}{l}\text { d. Empowerment } \\
\text { 1) Training for the manufacture of } \\
\text { processed meat products }\end{array}$ & $\begin{array}{l}\text { a) Facilities and infrastructure training } \\
\text { b) Learning and practice for making processed } \\
\text { food } \\
\text { c) Application of training results for } \\
\text { household consumption } \\
\text { a) Discussion on group activities } \\
\text { b)Implementation of main tasks and the } \\
\text { function of the Management. }\end{array}$ & $\begin{array}{l}\text { a) Application of training results to } \\
\text { develop product variants made from } \\
\text { moringa leaves } \\
\text { b)Business assistance } \\
\text { a) Fulfilling the needs of the group }\end{array}$ \\
\hline
\end{tabular}

The access owned by Ngudi Rejeki Women Farmer Group in developing local products, namely: land for cultivating plants; capital in the form of plants as the basic material for products, money, and equipment; as well as education in the form of counseling and training. This access does not only come from the village empowerment program but also comes from the central government and is according to their respective owners. Each access is managed individually or in groups according to ownership because Ngudi Rejeki Women Farmer Group members have the right to make decisions on this access based on considerations of themselves, other family members, or groups. The Ngudi Rejeki Women Farmer Group empowerment program organized by the government does not increase the workload for members because women farmers make time arrangements and determine priorities for each role that is carried out. Unfortunately, the development orientation that is still prioritized on physical development can hinder members' self-development because the empowerment program for Ngudi Rejeki Women Farmer Group is more oriented towards human resource development. The concentration of the program has been comprehensively carried out in the three roles played by women farmers, namely reproductive, productive, and social roles.

Based on the data in table 3, there are four of the five types of interventions related to the empowerment of the Ngudi Rejeki Women Farmer Group. This type of intervention, in other words, is a type of policy approach that can occur simultaneously or continuously with one another. The type of welfare intervention in the aid of drying moringa leaves fulfills the characteristic of top-down because it includes assistance from the government that can be used directly and is related to the role of women in reproductive activities, namely processing food for household consumption purposes and diversifying food within the family. Women farmers play a role in every development process through empowerment programs planned by the village government and become part of the Gapoktan parent organization with farmer groups so that the basic approach is equality because they have the same opportunity as men to be involved in the development process and Gapoktan. Programs or activities that are included in the antipoverty approach aim to increase the productivity of women farmers to earn income, through the assistance of moringa leaves drying tools that can facilitate the production process and the cultivating of moringa leaves can reduce expenses for buying foodstuffs. This type of empowerment intervention aims to empower women farmers to achieve independence individually or in groups. The next step identifies the realization of practical gender needs and the strategy of each type of intervention to determine the needs which have and have not done, the realization that: 
TABlE IV. Actual Fulfillment of THE Gender NeEdS

\begin{tabular}{|c|c|c|c|}
\hline \multirow{2}{*}{ Gender Needs } & \multicolumn{2}{|c|}{ Realization } & \multirow{2}{*}{ Specification } \\
\hline & Done & Not yet & \\
\hline \multicolumn{4}{|c|}{ Practical Gender Needs } \\
\hline $\begin{array}{l}\text { 1) Use of moringa leaves drying tools for } \\
\text { family consumption needs }\end{array}$ & $\checkmark$ & & $\begin{array}{l}\text { Tools are still used individually because not all members } \\
\text { need, and to make products that are used for household } \\
\text { consumption. }\end{array}$ \\
\hline $\begin{array}{l}\text { 2) Participating in deliberation forums in the } \\
\text { village }\end{array}$ & $\checkmark$ & & $\begin{array}{l}\text { Ngudi Rejeki Women Farmer Group still does not } \\
\text { understand the differences in the participated forums } \\
\text { respectively and the proposals are still disapproved. }\end{array}$ \\
\hline 3) Joined a Gapoktan organization & $\checkmark$ & & Has joined, but Gapoktan is less active \\
\hline 4) $\begin{array}{l}\text { Expenditures for group meetings are } \\
\text { reduced }\end{array}$. & $\checkmark$ & & Requirements for the disbursement of funds can be met. \\
\hline 5) Moringa plant maintenance & $\checkmark$ & & Most of the members cultivate the moringa plants. \\
\hline $\begin{array}{l}\text { 6) Use of moringa leaves for household } \\
\text { consumption }\end{array}$ & $\checkmark$ & & $\begin{array}{l}\text { Most members have processed moringa leaves for } \\
\text { household consumption such as vegetables, side dishes, } \\
\text { drinks. }\end{array}$ \\
\hline $\begin{array}{l}\text { 7) Use of moringa leaves drying tools for } \\
\text { production }\end{array}$ & $\checkmark$ & & $\begin{array}{l}\text { Tools are still used individually because not all members } \\
\text { need, and to make moringa beverage processed products. }\end{array}$ \\
\hline 8) Get money from selling processed products & $\checkmark$ & & $\begin{array}{l}\text { Ngudi Rejeki Women Farmer Group member has already } \\
\text { earned income from processed products. }\end{array}$ \\
\hline 9) Training facilities and infrastructure & $\checkmark$ & & $\begin{array}{l}\text { The equipment used for the training is accommodated by } \\
\text { Ngudi Rejeki Women Farmer Group who attended the } \\
\text { previous training. }\end{array}$ \\
\hline $\begin{array}{l}\text { 10) Learning and practice of making processed } \\
\text { food }\end{array}$ & $\checkmark$ & & $\begin{array}{l}\text { Training is accompanied by practice using the prepared } \\
\text { tools. }\end{array}$ \\
\hline $\begin{array}{l}\text { 11) Application of the training results on } \\
\text { processed meat for household consumption }\end{array}$ & $\checkmark$ & & $\begin{array}{l}\text { Only those who have the tools can apply the training } \\
\text { results. }\end{array}$ \\
\hline 12) Discussion of group activities & $\checkmark$ & & $\begin{array}{l}\text { The problems and group activities are discussed in group } \\
\text { meeting forums. }\end{array}$ \\
\hline $\begin{array}{l}\text { 13) Implementation of main duties and } \\
\text { functions of management }\end{array}$ & & $\checkmark$ & $\begin{array}{l}\text { Main duties and functions of management have not been } \\
\text { carried out optimally because of vacancies in certain areas } \\
\text { of management and the replacement of managers during } \\
\text { the management period. }\end{array}$ \\
\hline \multicolumn{4}{|c|}{ Strategic Gender Needs } \\
\hline $\begin{array}{l}\text { 1) Handling of certain problems by the village } \\
\text { government }\end{array}$ & $\checkmark$ & & $\begin{array}{l}\text { Ngudi Rejeki Women Farmer Group stated the problem to } \\
\text { the Head of Welfare section and tried to be followed up } \\
\text { by the village. }\end{array}$ \\
\hline 2) Active participation in Gapoktan & & $\checkmark$ & $\begin{array}{l}\text { Gapoktan is considered not active, so Ngudi Rejeki } \\
\text { Women Farmer Group has not been able to actively } \\
\text { participate in it. }\end{array}$ \\
\hline 3) Ongoing group meetings & $\checkmark$ & & $\begin{array}{l}\text { Ngudi Rejeki Women Farmer Group meetings are held } \\
\text { regularly every month. }\end{array}$ \\
\hline 4) Conservation of moringa plants & $\checkmark$ & & $\begin{array}{l}\text { Most of the members and villagers who have the desire to } \\
\text { cultivate this plant have conserved them by cultivating in } \\
\text { their yards, or gardens even though the Kelorization } \\
\text { program proposed in the village government forum has } \\
\text { not been followed up. }\end{array}$ \\
\hline 5) Sales of moringa leaves & $\checkmark$ & & $\begin{array}{l}\text { Members can sell moringa leaves to other members who } \\
\text { have a large production scale. }\end{array}$ \\
\hline 6) Ability to use promotional strategies & & $\checkmark$ & $\begin{array}{l}\text { Most members are not yet able to use promotional } \\
\text { strategies such as how to communicate in marketing } \\
\text { products. }\end{array}$ \\
\hline $\begin{array}{l}\text { 7) Application of training results to develop } \\
\text { product variants made from moringa leaves }\end{array}$ & & $\checkmark$ & $\begin{array}{l}\text { The results of the training have not been utilized to make } \\
\text { new variants of processed moringa continuously, but have } \\
\text { the potential to be developed by disadvantaged members. }\end{array}$ \\
\hline 8) Business assistance & & $\checkmark$ & $\begin{array}{l}\text { Some members are helpless due to lack of capital and } \\
\text { internal encouragement by waiting for help from other } \\
\text { members, while there is no business assistance due to lack } \\
\text { of resources and the busyness of each member. }\end{array}$ \\
\hline 9) Meeting group needs & $\checkmark$ & & $\begin{array}{l}\text { The group needs were discussed together in group } \\
\text { meetings, but there was a proposal that was not approved } \\
\text { by the village government, so Ngudi Rejeki Women } \\
\text { Farmer Group tried to find a solution on its own. }\end{array}$ \\
\hline
\end{tabular}


Referring to Table 5.8, it is known that there are practical and strategic gender needs that have not been met. In addition, there are still practical and strategic gender needs that have been met, but groups and village governments still need to pay attention to them so that they can be addressed. The decision-makers on the empowerment program for Ngudi Rejeki Women Farmer Group were carried out by the village government which was still dominated by men, women farmers as subjects as well as objects of development had a role to be involved in the development process, especially in development planning which played a role as forum participants and had the right to submit proposals. Benefits obtained include income from product sales, knowledge, and skills gained from counseling and training.

D. Formulation of Ngudi Rejeki Women Farmer Group Policy Program

Every year, Trirenggo Village develops the regional potential for the welfare of its people, including farmers and women farmers. Regional potential development involves various parties as well as existing resources. This development can be a potential for developing local products in Trirenggo Village that are processed by Ngudi Rejeki Women Farmer Group members. This potential is not only for developing local products, but also the opportunity to develop plant cultivation activities to realize food security and food diversification for rural communities. Opportunities in Trirenggo Village that have the potential to be developed are: (1) Village Market development planned by the village government to accommodate and trade local products owned by Trirenggo Village, in the preparation of the Medium-term Rural Development Plan (RPJMDes), there is the development of productive economic enterprises as well as development, utilization, and the maintenance of economic facilities and infrastructure including the Village Market [2], strategically located on the side of the main road not far from the office complex of Bantul Regency and the district center; (2) cultivation of edamame soybeans, edamame soybeans being tested for development in Trirenggo Village have a higher power and selling price than conventional soybeans, so that the opportunities for the welfare of farmers are higher and have the opportunity to be used as new processed products; (3) efforts for village food security in collaboration with the Damandiri Foundation through cultivating food plants around the rustic, food security itself is a person's ability to access and provide food, a household is called having food security if family members are not starving or threatened with hunger. So, food security in the family can be achieved [8]

Through gender analysis, programs and activities could be evaluated and studied using a needs approach to apply the women's development interpretation through the analysis criteria in the type of intervention. The opportunities that existed provide hope for solving existing problems. The development of local products was related to the products sold and other supporting aspects, such as the internal battle to improve living standards, processed resources, marketing, and the government's active role in realizing the welfare of its citizens. Development in the form of training is needed to have clear and visible objectives. Therefore, an empowerment policy program for the Ngudi Rejeki Women Farmer Group can be formulated by integrating it with a need and opportunity analysis, namely as follows:

\section{1) Coaching group organizing}

Inadequate understanding of the development planning process and the results of development planning that are not suitable to the expectations of Ngudi Rejeki Women Farmer Group can cause psychological impacts. The village government needs to provide provision to the Ngudi Rejeki Women Farmer Group with analytical skills to identify problems and their urgency to formulate needs and provide an understanding to the development planning forum. The analysis process was carried out to formulate physical and empowerment program proposals; and strengthen arguments during deliberation forums. As one of the village-level organizations that are based on Combined Farmer Group, there needs to be good communication and cooperation between Combined Farmer Group and Ngudi Rejeki Women Farmer Group so that Combined Farmer Group can be the spearhead that can provide support for the realization of every program needed by Ngudi Rejeki Women Farmer Group. Guidance for group organizing at the internal of Ngudi Rejeki Women Farmer Group needs to be done considering that the organization's sustainability requires regeneration and active members to support the smooth running of activities. Groups need clear rules on mutual agreement related to membership status and management in the group so that each member can be responsible for their participation in the Ngudi Rejeki Women Farmer Group. Continuity of management in running the organization can be done by fostering an understanding of each field's main tasks, functions, and increasing leadership capacity not to burden certain parties.

2) Conservation of moringa plants in the village environment

Plant cultivation is a way to achieve food security and food diversification. A foundation in collaboration with the village government can be used to realize food diversification efforts within the household sphere and realize the Kelorization program that Ngudi Rejeki Women Farmer Group has proposed. Moringa plants are known to have health benefits which have become an entity of Ngudi Rejeki Women Farmer Group as a group of manufacturers of moringa-based processed products that can promote the name of Trirenggo Village so it is necessary to preserve plants in the village environment. Relevant 
agencies have provided support for the preservation of moringa plants, so there is a need for synergy between stakeholders such as the village government, Ngudi Rejeki Women Farmer Group, and extension workers to conserve moringa plants in rural environments by making mutual agreements about which locations can be planted with these plants. By preserving this plant, both Ngudi Rejeki Women Farmer Group members and the general community of non-Ngudi Rejeki Women Farmer Group members who do not make processed products can use them for household consumption, thereby reducing expenses for buying food.

3) Development of marketing capabilities and networks

Products processed by Ngudi Rejeki Women Farmer Group members include local products owned by Trirenggo Village. The product did raise not only the group repute but also the village. The support of the village government to develop a product marketing network is needed so that the profits earned by producers will increase, and it can improve the welfare of its citizens. The village government can involve Ngudi Rejeki Women Farmer Group to place member products in the planned Village Market. Ngudi Rejeki Women Farmer Group needs to be equipped with promotion strategy skills through training and practice. The promotion strategy that is prioritized to be taught is how to communicate in marketing products. The village government can play a role in conducting training by involving competent parties.

This Village Market is a new shopping area, so there is a need for a promotional strategy to introduce this shopping place. In the digital era nowadays, the introduction and promotion process can be done with the help of social media. Village Market locations can be registered on google maps and integrated online product sales such as online shops, e-commerce, and marketplaces. Product sales are not only about goods transactions but the producers and sellers also need to have good communication skills in satisfying potential buyers and creating advertisements using copywriting techniques. The village government can work together with competent parties to assist Ngudi Rejeki Women Farmer Group in marketing products, so that is not only the facilities provided but also appoint competent Village Market managers. The management of the Village Market is carried out by the village government, which is managed separately from the village management. The village government can appoint managers from the local community to manage the village market with experience and knowledge in the economic field. The composition of the Village Market manager consists of the head of the market, the head of maintenance and order affairs, the head of administrative and financial affairs, and can be adjusted to the needs and conditions of each village, and can collaborate with third parties in the development and development of village markets [9].
4) Development of processed product variants made from moring a leaves

Moringa leaves are a food ingredient that can be substituted for various types of food. $56.25 \%$ of members who do not make processed products made from moringa leaves, with $18.75 \%$ have not developed themselves. This product variant development is prioritized for Ngudi Rejeki Women Farmer Group members who have not yet developed because other members have processed other products that already have their market share. There are training results and results of village crop commodities that can be developed, including training results in the manufacture of processed products made from meat and edamame soybeans. Processed products made from meat can be substituted using moringa leaf flour. A higher dose of moringa leaf flour can increase crude protein content and reduce crude fat and total cholesterol from nuggets [10]. Other products that can be developed are dairy products made from edamame (vegetable soybean) substituted with moringa leaves, the nutrients contained in edamame and moringa milk can be used as an innovative nutrient-rich beverage product that is an alternative to adding nutrients for children during their growth period, especially at age of 7-9 years [11], women farmers can take advantage of the edamame soybean production grown in the group demonstration plot or collaborate with village farmers who are farming edamame soybeans. Product processing requires processing skills, capital (money and equipment), and trading these processed products, so there needs to be assistance for underdeveloped members.

The mentoring process has obstacles in both personnel and activities. There needs to be selfstability to improve the standard of living and not only depend on the assistance of a companion. Assistance can be carried out by forming a companion team consisting of extension workers, empowered members, and other parties deemed competent and on duty for a certain period. The implementation can combine both offline and online methods. Assistance can be in the form of obtaining access to capital that is following economic capacity, testing product processing, laboratory testing and licensing of processed products, opening product market access and applying communication in marketing, managing capital so that the circulation of money can run smoothly, and encouraging participation in Micro, Small, and Medium Enterprises (MSMEs). The production process requires equipment and tools with a specific nominal price that producers cannot purchase, preventing producers from developing. The village government needs to carefully consider the assistance of the tools provided to be used both privately or in groups and the producer business plan. 


\section{CONCLUSION}

Local products that become the entity of Ngudi Rejeki Women Farmer Group are processed products made from moringa leaves, but not all Ngudi Rejeki Women Farmer Group members make processed products made from moringa leaves. Product development is supported through an empowerment program organized by the village government. These programs include: assistance for the moringa leaves drying tools, budget assistance for meetings, and training in the manufacture of processed meat-based products. The activity profile in the gender analysis shows that the activities attended by Ngudi Rejeki Women Farmer Group have accommodated the implementation of three roles, namely reproductive, productive, and social society. Practical and strategic gender needs are identified based on the type of intervention, namely welfare, equality, anti-poverty, and empowerment. There are practical and strategic gender needs that have not been implemented while those which have been implemented still have shortcomings that need to be corrected. Opportunities that could be potentially developed on the village products include village market development, edamame soybean cultivation, and village food security efforts. The empowerment policy program for Ngudi Rejeki Women Farmer Group is the group organization guidance, moringa plant cultivation in the village environment, capacity building and product marketing networks, development of processed product variants made from moringa leaves.

\section{REFERENCES}

[1] Undang-Undang Nomor 6 Tahun 2014 tentang Desa

[2] Peraturan Menteri Dalam Negeri Nomor 114 Tahun 2014 tentang Pedoman Pembangunan Desa

[3] G.G. Akbar, Y. Hermawan, A.L. Karlina, "Analisis Perencanaan Pembangunan Desa di Desa Sukamaju Kecamatan Cilawu Kabupaten Garut”, J. Pembangunan dan Kebijakan Publik, vol. 10, pp. 1-8, 2019.

[4] H. Christian, "Studi Tentang Pelaksanaan Rencana Kerja Pembangunan Desa (RKPDes) Tahun 2013 di Desa Loa Janan Ulu Kecamatan Loa Janan Kabupaten Kutai Kartanegara”, eJ. Pemerintahan Integratif, vol. 3, pp. 190210, 2015.

[5] H. Purnamasari and R. Ramdani, "Manajemen Pemerintahan dalam Pembangunan Desa Di Desa Lemahabang Kecamatan Lemahabang Kabupaten Karawang", J. Politikom Indonesiana, vol. 3, pp. 1-13, 2018

[6] Handayani, T. \& Sugiarti, "Konsep dan Teknik Penelitian Gender Edisi Revisi”, Malang : UMM Press, 2008.

[7] C. March, I. Smyth, and M. Mukhopadhyay, "A Guide to Gender-Analysis Frameworks”, Oxford: Oxfam, 1999

[8] D.I. Suryani, Prasetyaningsih, and L.T. Biru, "Literasi Ketahanan Pangan: Pemanfaatan Pekarangan Guna Mendukung Ketersediaan Pangan Bergizi", Prosiding Seminar Nasional Pendidikan FKIP, vol. 3, pp. 562-569, 2020

[9] Peraturan Menteri Dalam Negeri Nomor 42 Tahun 2007 tentang Pengelolaan Pasar Desa

[10] Z. Suhaemi, Husmaini, E. Yerizal, and N. Yessirita, "Pemanfaatan Daun Kelor (Moringa oleifera) dalam Fortifikasi Pembuatan Nugget", J. Ilmu Produksi dan Teknologi Hasil Peternakan, vol. 9, pp. 49-54, 2021.

[11] N.W.R. Dewi , S. Hamidah, and B. Lastariwati, "Susu Edamame Jelly Kelor Sebagai Alternatif Minuman untuk Perbaikan Gizi Anak", HEJ (Home Economics Journal), vol. 3, pp. 38-61, 2019. 